\title{
Extragonadal germinoma
}

INSERM

\section{Source}

INSERM. (1999). Orphanet: an online rare disease and orphan drug data base.

Extragonadal germinoma. ORPHA:182127

Extragonadal germinoma is a rare, malignant germ cell tumor that occur in the midline of the body as a result of abnormal germ cell migration during embryogenesis. Clinical manifestations are variable and depend on the location and size of the tumor. Central nervous system tumor might present with headache, visual disturbances, endocrine abnormalities, and signs of increased intracranial pressure. A mediastinal tumor commonly presents with chest pain, dyspnea, cough and fever. Abdominal mass with or without pain, backache and weight loss are common clinical presentations in retroperitoneal tumor. 